\title{
Effect of Some Postharvest Treatments on Storage Quality of Apple cv. Royal Delicious under Ambient Storage
}

\author{
Sharma Anshu* \\ Division of Food Science and Technology, Dr. Yashwant Singh Parmar University of \\ Horticulture and Forestry, Nauni, Solan - 173230 (H.P.) India \\ *Corresponding author
}

\section{A B S T R A C T}

\section{Keywords \\ Apple, Postharvest treatments, 1-MCP, \\ Starlight waxing, Leaf extracts, aCl2, Loss in weight, Fruit firmness, Total soluble solids, Reducing and total sugars, Titratable acidity, Pectin content, Starch-iodine rating, Respiration rate, Sensory evaluation, Spoilage}

\section{Article Info}

Accepted:

07 March 2019

Available Online:

10 April 2019
All the treatments showed a beneficial effect on physical, biochemical and sensory parameter of fruits in comparison to control fruits. Among all treatments, $1250 \mathrm{ppb} 1-\mathrm{MCP}$ was proved to be the best in retaining the storage quality of fruits under ambient storage. After applying 1-Methylcyclopropene (1-MCP), Aloe vera leaf extracts alone and in combination with $\mathrm{CaCl}_{2}$ and Starlight waxing treatments, fruits were stored under ambient conditions for 45 days, respectively. These treatments in general, slowed down the physiological changes and respiration rate of fruits, thereby proving to be effective in maintaining fruit quality during ambient storage. 1-MCP (1250 ppb) was the most effective treatment in this regard as the fruits retained maximum firmness, titratable acidity and exhibited lower decreases in physiological loss in weight, starch disappearance besides showing lower changes in TSS and sugar contents. Starlight waxing (75\%) and Aloe vera leaf extracts, especially in combination with 1 per cent $\mathrm{CaCl}_{2}$ were also quite effective in retaining quality of fruits in comparison to control fruits. These fruits also had higher sensory evaluation rating and hence the best overall acceptability ratings. However, Aloe vera whole leaf extract in combination with 1.0 per cent $\mathrm{CaCl}_{2}$ efficiently reduced spoilage of fruit due to rots during storage.

\section{Introduction}

Apple, the premier table fruit of the world, belongs to the family Rosaceae and sub family Pomoideae. It is an important temperate fruit crop of the world with an annual production of 63.8 million metric tonnes from an area of 4.79 million hectares (FAO, 2008), with more than 80 per cent of the world's supply being produced in Europe (Asif, 2002). In India it is predominantly grown in the North-Western Himalayan region comprising of Jammu and Kashmir, Himachal Pradesh and Uttarakhand. Its cultivation has been extended to Arunachal Pradesh, Sikkim, Nagaland and Meghalaya in the North-Eastern region and Nilgiri hills in Tamil Nadu (Awasthi and Chauhan, 2002). Its attractive appearance, crispy flesh, pleasant flavour and sweet taste attract the consumers and fetch high price. It is an important source of vitamin $\mathrm{C}$, vitamin $\mathrm{A}$, thiamin and other 
vitamin complexes. About 1,739,000 metric tonnes of apples are reported to be produced in India annually (FAO, 2008).

Being a climacteric fruit, apple produces large amounts of ethylene during ripening as a result of which the fruit that reaches the consumers is usually in an over ripe stage. Such fruits also show marked losses in quality during storage. It is therefore necessary to reduce such losses by the use of simple technology which can be used by the growers right in their orchards. Such postharvest losses can be overcome by the use of appropriate postharvest treatments that have the potential to reduce spoilage and respiratory and transpirational losses by use of suitable chemicals, waxing material, natural extracts and storage conditions.

1-Methylcyclopropene (1-MCP) is an antagonist of ethylene action that binds to the ethylene receptor molecule in the tissues after treatment of fruits and delays ripening and the associated changes that are generally induced and accelerated by ethylene and it is being used extensively in horticulturally advanced countries. The application of plant nutrients like calcium $(\mathrm{Ca})$ in the form of calcium chloride has also been reported to maintain cell integrity and firmness of fruits during storage. It is also believed to be involved as an anti-ripening and anti-senescence agent in fruit (Lester and Grusak, 1999; Betts and Bramlage, 1977), preventing cellular disorganization by maintaining protein and nucleic acid synthesis (Faust and Klein, 1974). Recently, there has been an increased interest in using Aloe vera gel as an edible coating material for fruits and vegetables driven by its antifungal activity (MartinezRomero et al., 2003; Saks et al., 1995 and Rodriguez de Jasso et al., 2005). In addition to the traditional role of edible coatings as a barrier to water loss and delaying fruit senescence, new generation coatings are being designed for incorporating and/or for controlled release of antioxidants, nutraceuticals, chemical additives and natural antimicrobial agents (Vargas et al., 2008). Coating of fruits with wax emulsions immediately after harvest, act as a barrier to the diffusion of $\mathrm{O}_{2}$ and $\mathrm{CO}_{2}$ into and out of fruit, thereby reducing respiratory and transpirational processes.

\section{Materials and Methods}

Freshly harvested Royal Delicious apple fruits were procured from a well maintained commercial orchard in Devidhar village, Tehsil Rohru, Distt. Shimla (HP). Immediately after harvest fruits were properly packed in Corrugated Fibre Board (CFB) cartons with paper moulded trays and were promptly transported to the Postharvest Physiology Laboratory, Department of Food Science and Technology for conducting the studies. The research was conducted in the Department of Postharvest Technology, Dr. Yashwant Singh Parmar University of Horticulture and Forestry, Nauni, Solan (H.P.) during the year 2010-11.

\section{Details of treatments}

After transportation of apple fruits to the Department of Food Science and Technology, the fruits were sorted and injured and blemished fruits were discarded. Fresh and uniform medium sized fruits were selected for the application of various postharvest treatments.

1-Methylcyclopropene (1-MCP) was applied as a fumigation treatment by placing the fruits in a closed tent with a calculated amount of chemical dissolved in water and a battery operated fan for 24 hours. Starlight wax manufactured by Pontes Industria de Cera Lida., Brazil was used for waxing of fruits. Wax solutions of different concentrations viz. 
25, 50 and 75 per cent were prepared with water dilution in which fruits were dipped for 1 minute. Fruits were air dried in shade by spreading them on filter paper sheets under a fan at ambient condition.

Aqueous extracts of Aloe vera were prepared under laboratory condition on per cent basis as per the method described by Gakhukar
(1996) and Sharma et al., (1997). Aloe vera leaf extracts were prepared by grinding whole leaf, leaf peel and leaf gel separately in an electric blender. The aqueous extracts were diluted by adding appropriate quantity of distilled water to make up the desired concentration. Various concentrations of these treatments were applied to fruits as per details mentioned below.

\begin{tabular}{|l|l|}
\hline TREATMENT NO. & TREATMENT DETAILS \\
\hline $\mathbf{T}_{\mathbf{1}}$ & 1-MCP $(750 \mathrm{ppb})$ \\
\hline $\mathbf{T}_{\mathbf{2}}$ & 1-MCP $(1000 \mathrm{ppb})$ \\
\hline $\mathbf{T}_{\mathbf{3}}$ & 1-MCP $(1250 \mathrm{ppb})$ \\
\hline $\mathbf{T}_{\mathbf{4}}$ & Aloe vera whole leaf extract \\
\hline $\mathbf{T}_{\mathbf{5}}$ & Aloe vera leaf peel extract \\
\hline $\mathbf{T}_{\mathbf{6}}$ & Aloe vera leaf gel extract \\
\hline $\mathbf{T}_{\mathbf{7}}$ & Aloe vera whole leaf extract $+\mathrm{CaCl}_{2}(1 \%)$ \\
\hline $\mathbf{T}_{\mathbf{8}}$ & Aloe vera leaf peel extract $+\mathrm{CaCl}_{2}(1 \%)$ \\
\hline $\mathbf{T}_{\mathbf{9}}$ & Aloe vera leaf gel extract $+\mathrm{CaCl}_{2}(1 \%)$ \\
\hline $\mathbf{T}_{\mathbf{1 0}}$ & Waxing - Starlight $(25 \%)$ \\
\hline $\mathbf{T}_{\mathbf{1 1}}$ & Waxing - Starlight $(50 \%)$ \\
\hline $\mathbf{T}_{\mathbf{1 2}}$ & Waxing - Starlight $(75 \%)$ \\
\hline $\mathbf{T}_{\mathbf{1 3}}$ & Control \\
\hline
\end{tabular}

\section{Fruit storage and analysis}

Fruits from all the treatments and replications were packed in CFB cartons for their storage under ambient conditions. Observations regarding physico-chemical characteristics of fruits were recorded at fortnightly intervals for fruits stored under ambient conditions. Physico-chemical analysis of fruits

\section{Physical characteristics}

\section{Fruit weight/Physiological loss in weight (PLW)}

At the start of the experiment marked fruits were weighed using a digital balance and the same fruits were weighed at an interval of 15 days under ambient conditions. The loss in weight at each interval during storage was expressed as percent of initial weight for every sample.

\section{Fruit firmness}

The fruit firmness was measured with a portable Effigi penetrometer (FT-327) which recorded the pressure required to force a plunger of $11 \mathrm{~mm}$ diameter into the flesh of pared fruit samples. The readings were taken on diagonally opposite sides of each fruit and results expressed in $1 \mathrm{bs} / \mathrm{sq}$. inch.

\section{Biochemical characteristics}

\section{Total soluble solids}

The total soluble solid (TSS) contents in fruit juice were recorded with the help of an Erma hand refractometer. Few drops of juice were 
squeezed from the fruit on to the prism of the refractometer and readings were observed through the eye piece. For accurate measurement the readings taken were corrected for temperature variations to $20^{\circ} \mathrm{C}$ and results expressed as ${ }^{0}$ Brix (Ranganna, 1986).

\section{Titratable acidity (TA)}

A known weight of the fruit sample was crushed and taken in a $100 \mathrm{ml}$ volumetric flask and the volume was made up by adding distilled water. After filtration, $10 \mathrm{ml}$ of the filtrate was taken in a separate conical flask and titrated against $0.1 \mathrm{~N}$ sodium hydroxide using phenolphthalein as an indicator. The end point was determined by the appearance of a faint pink colour. Titratable acidity was calculated and expressed as per cent malic acid (Ranganna, 1986).

\section{Reducing sugars}

Reducing sugar contents were estimated by the Lane and Eynon's volumetric method (Ranganna, 1986). Samples were prepared by crushing weighed quantity of fruit, and making a known volume followed by titration against a known volume of Fehling's solutions using methylene blue as an indicator. The appearance of brick red precipitate was noted as the end point. The results are expressed as percent reducing sugar content.

\section{Total sugars}

The total sugar contents were also estimated by Lane and Eynon's volumetric method (Ranganna, 1986) by titrating the prepared sample, after hydrolysis with citric acid, against a known quantity of Fehling's solution using methylene blue as an indicator. The end point was attained when a brick red precipitate appeared in the solution. The results are expressed as percent total sugar.

\section{Pectin content}

Pectin content of the fruit was determined by Carre and Hayne's method as described by Ranganna (1986). The pectin extracted from the fruit was saponified with alkali and precipitated as calcium pectate from an acid solution by the addition of calcium chloride. The results are expressed as per cent calcium pectate.

\section{Starch-iodine rating}

The disappearance of starch in a section of fruit was evaluated by the 'starch-iodine test' as described by Phillips and Poapst (1959). The extent of the disappearance of starch in the fruits was categorized into nine stages by assigning numerical values from 1 to 9 to each of these stages. The starch content decreased as the numerical rating increased from 1 to 9 .

\section{Respiration rate}

Respiration rate of fruits was analyzed with the help of $\mathrm{O}_{2}$ and $\mathrm{CO}_{2}$ analyzer (GFM 100 series, GAS Data Ltd.). At first, weight of fruit was recorded and the fruits were kept into a closed glass jar for an hour. The rate of respiration was recorded as $\mathrm{ml} \mathrm{CO} / \mathrm{kg} / \mathrm{hr}$.

\section{Sensory evaluation}

To assess consumer preference, sensory evaluation of experimental samples was conducted at different intervals of storage by a panel of judges, consisting of teachers, students and other staff members.

The panelists were given coded samples consisting of whole fruits and slices for giving their views on overall acceptability of the fruit. The evaluation was done by using the 9point hedonic scale for each attribute (Wills et al., 1980). 


\section{Fruit spoilage}

Fruits spoiled due to fungal rots were counted at every storage interval and the total number was calculated by adding up all the diseased fruits from successive storage intervals. The spoilage percent was calculated by dividing the number of fruits spoiled by the total number of fruits stored and multiplying the result by 100 .

\section{Statistical analysis}

The effect of various postharvest treatments of 1-Methylcyclopropene (1-MCP), Aloe vera leaf extracts, calcium chloride and waxing on fruit quality were assessed by Completely Randomized Design (CRD) whereas data pertaining to sensory evaluation was analyzed by randomized block design (RBD).

\section{Results and Discussion}

\section{Physical characteristics}

\section{Physiological loss in weight (PLW)}

Data pertaining to the effect of various postharvest treatments on physiological loss in weight (PLW) of apple fruits cv. Royal Delicious during ambient storage has been presented in the Table 1. The maximum mean PLW $(6.36 \%)$ was recorded in control fruits which was significantly higher in comparison to all other treatments. Minimum mean PLW $(5.0 \%)$ was recorded by application of 1250 ppb 1-MCP $\left(\mathrm{T}_{3}\right)$ and it was followed by waxing with 75 per cent Starlight $\left(\mathrm{T}_{12}\right)$ and $1000 \mathrm{ppb} 1-\mathrm{MCP}\left(\mathrm{T}_{2}\right)$ respectively, although all these treatments were statistically at par. Treatments with extracts of different portions of Aloe vera leaf alone and in combination with $\mathrm{CaCl}_{2}$ and lower concentration of Starlight wax were also effective in reducing PLW in comparison to controls. During storage an increase in PLW was observed with each successive sampling date under all treatments. The interaction between treatments and storage intervals was found to be significant. It was observed that all postharvest treatments were effective in decreasing physiological loss in weight (PLW) of fruits during ambient storage. The most effective treatment in this regard was fumigation with 1-Methylcyclopropene (1MCP) though coating with Starlight wax and Aloe vera leaf extract, especially in combination with $\mathrm{CaCl}_{2}$ were also quite effective. Physiological loss in weight of fruits during storage is believed to be due to losses of stored metabolites because of their utilization during respiration and loss of water. Water loss from fruits and vegetables is mainly due to transpiration although some of it may be lost by respiration and evaporation (Wilkinson, 1965). Moisture loss due to transpiration and evaporation is higher if the differences between surrounding and internal vapour pressure of the commodity is greater and such conditions can be seen when commodities are left unprotected. Conversely any coating material that creates an additional barrier to prevent moisture loss from the fruit surface can be expected to decrease moisture loss.

\section{Fruit firmness}

Data pertaining to the changes in fruit firmness of apple fruits cv. Royal Delicious as affected by various postharvest treatments during ambient storage is presented in the Table 2. From the data it is evident that there was a decrease in fruit firmness under all treatments as the storage period progressed. Among the various treatments tried $1250 \mathrm{ppb}$ 1-MCP $\left(\mathrm{T}_{3}\right)$ was most effective in reducing the decrease and hence resulted in maximum mean firmness (12.45 lbs/sq. inch) of fruits which was significantly higher in comparison to all other treatments. Aloe vera leaf extracts, especially in combination with 1.0 per cent 
$\mathrm{CaCl}_{2}$, and Starlight waxing were also quite effective in retaining fruit firmness during storage. On the other hand minimum mean firmness was recorded in control which was significantly lower than all other treatments. 1-MCP has the potential to control ethylene action by blocking ethylene receptors (Sisler and Serek, 1997) thereby preventing or delaying changes associated with fruit ripening and hence maintaining fruit quality, mainly fruit firmness, not only during storage but also during the marketing and shelf-life periods (Streif, 2007).

\section{Biochemical characteristics}

\section{Total soluble solids (TSS), Reducing sugars and Total sugars}

Effects of various postharvest treatments on TSS content of apple fruits were recorded during ambient storage conditions and were expressed by the data presented in Table 3 . The increase in TSS content of control fruits was observed only up to 15 days after which a faster decline was noticed resulting in the lowest TSS content by the last day of sampling; consequently resulting in the lowest mean value of $11.51^{\circ}$ Brix. Changes in TSS content as a result of other treatments were more gradual with Starlight waxing ( $\mathrm{T}_{11}$ and $\left.\mathrm{T}_{12}\right)$ and Aloe vera leaf extracts $\left(\mathrm{T}_{6}, \mathrm{~T}_{4}\right.$ and $\mathrm{T}_{5}$ ) being more effective in retaining higher TSS levels although all the treatments, excepting $T_{3}$, were statistically at par. The minimum mean reducing sugars content $(5.75 \%)$ was recorded in control fruits and it was significantly lower in comparison to all other treatments (Table 4). Among the other treatments fruit treated with 1-MCP in general had the lowest reducing sugar content. The maximum reducing sugar content $(6.41 \%)$ was recorded in fruits treated with Aloe vera leaf peel extract $\left(\mathrm{T}_{5}\right)$ and it was followed by $\mathrm{T}_{4}, \mathrm{~T}_{10}, \mathrm{~T}_{12}$ and $\mathrm{T}_{6}$, although all the treatments were statistically at par. The maximum mean total sugars content was recorded in fruits treated with Aloe vera leaf peel extract $\left(\mathrm{T}_{5}\right)$ and Starlight waxing treatments $\left(\mathrm{T}_{11}\right.$ and $\left.\mathrm{T}_{12}\right)$ where it was 8.44 per cent and these treatments were followed by $\mathrm{T}_{4}, \mathrm{~T}_{10}, \mathrm{~T}_{6}$ and $\mathrm{T}_{8}$, with all these treatments being statistically at par (Table 5). Minimum mean total sugars content was recorded in fruits treated with 1MCP as it resulted in the most gradual changes in total sugars content although these fruits had comparably high total sugars content on the last sampling date. Total soluble solids (TSS), total sugars and reducing sugars contents of fruit in general, increased during the initial storage period and subsequently declined towards the end of storage in all treatments. The increase in TSS and sugar contents during storage may possibly be due to breakdown of complex organic metabolites into simple molecules or due to hydrolysis of starch into sugars, and on complete hydrolysis of starch no further increase in sugars occurred. Subsequently a decline in these parameters is evident as they along with other organic acids are the primary substrates for respiration (Wills et al., 1980). The higher TSS and sugars content in control fruits during the initial sampling dates might be due to faster ripening changes resulting in breakdown of complex carbohydrates into simple sugars at a faster rate thereby increasing these constituents to the maximum extent and also due to the higher transpirational losses (Suni et al., 2000) thereby having a concentration effect.

\section{Titratable acidity (TA)}

Data depicting the effect of various postharvest treatments on titratable acidity (TA) of apple fruits during ambient storage has been presented in Table 6. During storage, titratable acidity levels in fruits decreased significantly under all treatments, with the decrease being more rapid in control fruits which exhibited the lowest values for TA on 
each sampling date and also the lowest overall mean TA content. Therefore, maximum mean TA $(0.27 \%)$ was recorded with the application of $1250 \mathrm{ppb} 1-\mathrm{MCP}\left(\mathrm{T}_{3}\right)$ and it was followed by $T_{2}$ and then jointly by $T_{1}, T_{9}$ and $T_{12}$. The interaction between treatments and storage intervals was found to be significant. The decline was slowest in 1-MCP treated fruits, probably due to its ability to lower the rate of respiration, thereby delaying changes which are associated with ripening and senescence. However, the lowest mean titratable acidity was recorded in the control fruits, which can be ascribed to high metabolic activities resulting in utilization of organic acids as respiratory substrates during prolonged storage (Ulrich, 1974). Ball (1997) suggested that acidity decreases due to fermentation or break up of acids to sugars in fruits during respiration.

\section{Pectin content}

Data depicting the effect of various postharvest treatments on pectin content of apple fruits cv. Royal Delicious during ambient storage is presented in the Table 7. The maximum mean pectin content $(1.31 \%)$ was recorded in fruits treated with Aloe vera leaf peel extract +1 per cent $\mathrm{CaCl}_{2}\left(\mathrm{~T}_{8}\right)$ and it was followed by Aloe vera whole leaf extract +1 per cent $\mathrm{CaCl}_{2}\left(\mathrm{~T}_{7}\right)$ and then by $1250 \mathrm{ppb}$ 1-MCP $\left(\mathrm{T}_{3}\right)$ and Aloe vera gel extract with $\mathrm{CaCl}_{2}\left(\mathrm{~T}_{9}\right)$, respectively. The minimum pectin content was noticed in control fruits and it was significantly lower in comparison to all other treatments. The pectin content generally decreased with an increase in storage duration. The interaction between treatments and storage intervals was found to be significant. The degradation of pectin is controlled by the activity of pectic enzymes and their regulation by appropriate treatments may have beneficial effects in extending the storage life of fruits. The loss in pectin may be due to its break down during storage (Doesburg, 1957 and Sandhu et al., 1990).

\section{Starch-iodine rating}

Data pertaining to the effect of various postharvest treatments on starch-iodine rating of apple fruits cv. Royal Delicious during ambient storage is presented in Table 8. From the data it is evident that minimum mean starch-iodine rating was recorded in $\mathrm{T}_{3}(1250$ ppb 1-MCP) and it was significantly lower than that in all other treatments and was followed by $T_{2}, T_{1}$ and $T_{12}$, respectively. Fruits treated with Aloe vera leaf extract also exhibited lower starch-iodine rating values in comparison to controls and the addition of $\mathrm{CaCl}_{2}$ in these extracts caused a further decrease in starch iodine rating values. The starch-iodine rating values generally increased with an increase in storage duration under all the treatments. The interaction between treatments and storage intervals was found to be significant. Starch-iodine rating is an important parameter to determine the starch content in fruits. Highest rating was recorded in control fruits which might be due to the hydrolysis of starch into sugars during metabolic processes due to increase in respiration rate with the passage of storage period. Lowest rating was recorded in fruits treated with 1-MCP which might be due to its ability to reduce the rate of metabolism due to inhibition of ethylene action and the concomitant conversion of starch into sugars. Wills et al., (1980) reported that with the advancement in storage period starch of apple get hydrolyzed and reaches to a level where it is undetectable by starch-iodine test.

\section{Effect on respiration rate}

Data pertaining to the effect of various postharvest treatments on rate of respiration of apple fruits cv. Royal Delicious during ambient storage is presented in the Table 9. 1MCP treatments generally resulted in lowering the respiration rate on all sampling dates with its effect being proportional to the 
concentration applied. Hence, the minimum rate of respiration was recorded in fruits treated with $1250 \mathrm{ppb} 1-\mathrm{MCP}\left(\mathrm{T}_{3}\right)$ which was significantly lower in comparison to all other treatments. Treatments with Aloe vera leaf extracts in general recorded higher respiration rates and the incorporation of 1 per cent $\mathrm{CaCl}_{2}$ in the extracts of different leaf parts tended to reduce the respiration rate in comparison to extracts of respective leaf parts alone.

Table.1 Effect of postharvest treatments on changes in physiological loss in weight* (\%) of apple fruits cv. Royal Delicious during ambient storage

\begin{tabular}{|c|c|c|c|c|}
\hline \multirow[t]{2}{*}{ Treatments $(\mathrm{T})$} & \multicolumn{4}{|c|}{ Storage Interval in days (I) } \\
\hline & 15 & 30 & 45 & Mean \\
\hline $\mathrm{T}_{1}: 1-\mathrm{MCP}(750 \mathrm{ppb})$ & $\begin{array}{c}4.65 \\
(2.16)\end{array}$ & $\begin{array}{c}5.10 \\
(2.26)\end{array}$ & $\begin{array}{c}5.58 \\
(2.36)\end{array}$ & $\begin{array}{c}5.11 \\
(2.26)\end{array}$ \\
\hline $\mathrm{T}_{2}: 1-\mathrm{MCP}(1000 \mathrm{ppb})$ & $\begin{array}{c}4.55 \\
(2.13)\end{array}$ & $\begin{array}{c}5.03 \\
(2.24)\end{array}$ & $\begin{array}{c}5.53 \\
(2.35)\end{array}$ & $\begin{array}{c}5.04 \\
(2.24)\end{array}$ \\
\hline $\mathrm{T}_{3}: 1-\mathrm{MCP}(1250 \mathrm{ppb})$ & $\begin{array}{c}4.53 \\
(2.13)\end{array}$ & $\begin{array}{c}4.99 \\
(2.23)\end{array}$ & $\begin{array}{c}5.50 \\
(2.35)\end{array}$ & $\begin{array}{c}5.00 \\
(2.24)\end{array}$ \\
\hline $\mathrm{T}_{4}$ : Aloe vera whole leaf extract & $\begin{array}{c}5.52 \\
(2.35)\end{array}$ & $\begin{array}{c}5.90 \\
(2.43)\end{array}$ & $\begin{array}{c}6.34 \\
(2.52)\end{array}$ & $\begin{array}{c}5.92 \\
(2.43)\end{array}$ \\
\hline $\mathrm{T}_{5}:$ Aloe vera leaf peel extract & $\begin{array}{c}5.62 \\
(2.37)\end{array}$ & $\begin{array}{c}6.11 \\
(2.47)\end{array}$ & $\begin{array}{c}6.62 \\
(2.57)\end{array}$ & $\begin{array}{c}6.12 \\
(2.47)\end{array}$ \\
\hline $\mathrm{T}_{6}$ : Aloe vera leaf gel extract & $\begin{array}{c}5.50 \\
(2.35)\end{array}$ & $\begin{array}{c}5.68 \\
(2.38)\end{array}$ & $\begin{array}{c}6.10 \\
(2.47)\end{array}$ & $\begin{array}{c}5.76 \\
(2.39)\end{array}$ \\
\hline $\mathrm{T}_{7}$ : Aloe vera whole leaf extract $+\mathrm{CaCl}_{2}(1 \%)$ & $\begin{array}{c}5.04 \\
(2.25)\end{array}$ & $\begin{array}{c}5.50 \\
(2.35)\end{array}$ & $\begin{array}{c}6.06 \\
(2.46)\end{array}$ & $\begin{array}{c}5.53 \\
(2.35)\end{array}$ \\
\hline $\mathrm{T}_{8}:$ Aloe vera leaf peel extract $+\mathrm{CaCl}_{2}(1 \%)$ & $\begin{array}{c}5.46 \\
(2.34)\end{array}$ & $\begin{array}{c}5.91 \\
(2.43)\end{array}$ & $\begin{array}{c}6.35 \\
(2.51)\end{array}$ & $\begin{array}{c}5.91 \\
(2.43)\end{array}$ \\
\hline $\mathrm{T}_{9}:$ Aloe vera leaf gel extract $+\mathrm{CaCl}_{2}(1 \%)$ & $\begin{array}{c}4.92 \\
(2.22)\end{array}$ & $\begin{array}{c}5.35 \\
(2.31)\end{array}$ & $\begin{array}{c}5.89 \\
(2.43)\end{array}$ & $\begin{array}{c}5.38 \\
(2.32)\end{array}$ \\
\hline $\mathrm{T}_{10}$ : Waxing-Starlight (25\%) & $\begin{array}{c}4.70 \\
(2.17)\end{array}$ & $\begin{array}{c}5.18 \\
(2.28)\end{array}$ & $\begin{array}{c}5.65 \\
(2.38)\end{array}$ & $\begin{array}{c}5.18 \\
(2.27)\end{array}$ \\
\hline $\mathrm{T}_{11}:$ Waxing-Starlight (50\%) & $\begin{array}{c}4.48 \\
(2.12)\end{array}$ & $\begin{array}{c}5.10 \\
(2.26)\end{array}$ & $\begin{array}{c}5.72 \\
(2.39)\end{array}$ & $\begin{array}{c}5.10 \\
(2.26)\end{array}$ \\
\hline $\mathrm{T}_{12}:$ Waxing-Starlight $(75 \%)$ & $\begin{array}{c}4.40 \\
(2.10)\end{array}$ & $\begin{array}{c}5.06 \\
(2.25)\end{array}$ & $\begin{array}{c}5.57 \\
(2.36)\end{array}$ & $\begin{array}{c}5.01 \\
(2.24)\end{array}$ \\
\hline $\mathrm{T}_{13}$ : Control & $\begin{array}{c}5.70 \\
(2.39)\end{array}$ & $\begin{array}{c}6.40 \\
(2.53)\end{array}$ & $\begin{array}{c}6.98 \\
(2.64)\end{array}$ & $\begin{array}{c}6.36 \\
(2.52)\end{array}$ \\
\hline Mean & $\begin{array}{c}5.01 \\
(2.23)\end{array}$ & $\begin{array}{c}5.48 \\
(2.34)\end{array}$ & $\begin{array}{c}5.99 \\
(2.45)\end{array}$ & \\
\hline \multicolumn{5}{|l|}{$\mathrm{CD}_{0.05}$} \\
\hline Treatments (T) & & & & \\
\hline Storage Interval (I) & & & & \\
\hline Tx I & & & & \\
\hline
\end{tabular}

*Figures in parentheses are square root transformed values 
Table.2 Effect of postharvest treatments on changes in fruit firmness (lbs/sq. inch) of apple fruits cv. Royal Delicious during ambient storage

\begin{tabular}{|c|c|c|c|c|}
\hline \multirow[t]{2}{*}{ Treatments $(\mathbf{T})$} & \multicolumn{4}{|c|}{ Storage Interval in days (I) } \\
\hline & 15 & 30 & 45 & Mean \\
\hline $\mathrm{T}_{1}: 1-\mathrm{MCP}(750 \mathrm{ppb})$ & 14.27 & 12.40 & 9.62 & 12.10 \\
\hline $\mathrm{T}_{2}: 1-\mathrm{MCP}(1000 \mathrm{ppb})$ & 14.48 & 12.55 & 9.80 & 12.28 \\
\hline $\mathrm{T}_{3}: 1-\mathrm{MCP}(1250 \mathrm{ppb})$ & 14.62 & 12.78 & 9.96 & 12.46 \\
\hline $\mathrm{T}_{4}$ : Aloe vera whole leaf extract & 13.90 & 11.32 & 8.72 & 11.32 \\
\hline $\mathrm{T}_{5}$ : Aloe vera leaf peel extract & 13.58 & 10.90 & 8.48 & 10.99 \\
\hline $\mathrm{T}_{6}$ : Aloe vera leaf gel extract & 14.10 & 11.68 & 8.86 & 11.55 \\
\hline $\begin{array}{l}\mathrm{T}_{7}: \text { Aloe vera } \text { whole leaf extract }+\mathrm{CaCl}_{2} \\
(1 \%)\end{array}$ & 14.42 & 12.50 & 9.65 & 12.19 \\
\hline $\begin{array}{l}\mathrm{T}_{8} \text { : Aloe vera leaf peel extract }+\mathrm{CaCl}_{2} \\
(1 \%)\end{array}$ & 14.25 & 12.36 & 9.58 & 12.06 \\
\hline $\begin{array}{l}\mathrm{T}_{9} \text { : Aloe vera leaf gel extract }+\mathrm{CaCl}_{2} \\
(1 \%)\end{array}$ & 14.58 & 12.72 & 9.72 & 12.34 \\
\hline $\mathrm{T}_{10}$ : Waxing-Starlight (25\%) & 13.96 & 11.38 & 8.85 & 11.40 \\
\hline $\mathrm{T}_{11}$ : Waxing-Starlight (50\%) & 14.08 & 11.46 & 8.99 & 11.51 \\
\hline $\mathrm{T}_{12}$ : Waxing-Starlight (75\%) & 14.20 & 11.62 & 9.05 & 11.63 \\
\hline $\mathrm{T}_{13}$ : Control & 12.29 & 9.38 & 8.40 & 10.02 \\
\hline Mean & 14.06 & 11.77 & 9.21 & \\
\hline \multicolumn{5}{|l|}{ Initial value: $17.5 \mathrm{lbs} / \mathrm{sq}$. inch } \\
\hline \multicolumn{5}{|l|}{$\mathrm{CD}_{0.05}$} \\
\hline Treatments (T) & & & & \\
\hline Storage Interval (I) & & & & \\
\hline $\mathrm{T} \times \mathrm{I}$ & & & & \\
\hline
\end{tabular}


Table.3 Effect of postharvest treatments on changes in total soluble solids (TSS) contents ( $\left.{ }^{\circ} \mathrm{Brix}\right)$ of apple fruits cv. Royal Delicious during ambient storage

\begin{tabular}{|c|c|c|c|c|}
\hline \multirow[t]{2}{*}{ Treatments (T) } & \multicolumn{4}{|c|}{ Storage Interval in days (I) } \\
\hline & 15 & 30 & 45 & Mean \\
\hline $\mathrm{T}_{1}: 1-\mathrm{MCP}(750 \mathrm{ppb})$ & 12.27 & 13.35 & 12.13 & 12.58 \\
\hline $\mathrm{T}_{2}: 1-\mathrm{MCP}(1000 \mathrm{ppb})$ & 12.13 & 13.03 & 12.55 & 12.57 \\
\hline $\mathrm{T}_{3}: 1-\mathrm{MCP}(1250 \mathrm{ppb})$ & 11.99 & 12.87 & 12.42 & 12.43 \\
\hline $\mathrm{T}_{4}$ : Aloe vera whole leaf extract & 12.76 & 13.62 & 11.70 & 12.69 \\
\hline $\mathrm{T}_{5}$ : Aloe vera leaf peel extract & 12.82 & 13.70 & 11.56 & 12.69 \\
\hline $\mathrm{T}_{6}:$ Aloe vera leaf gel extract & 12.22 & 13.28 & 12.59 & 12.70 \\
\hline $\begin{array}{l}\mathrm{T}_{7}: \text { Aloe vera whole leaf extract }+\mathrm{CaCl}_{2} \\
(1 \%)\end{array}$ & 12.18 & 13.12 & 12.62 & 12.64 \\
\hline $\begin{array}{l}\mathrm{T}_{8}: \text { Aloe vera leaf peel extract }+\mathrm{CaCl}_{2} \\
(1 \%)\end{array}$ & 12.43 & 13.48 & 12.05 & 12.65 \\
\hline $\mathrm{T}_{9}:$ Aloe vera leaf gel extract $+\mathrm{CaCl}_{2}(1 \%)$ & 12.64 & 13.49 & 11.74 & 12.62 \\
\hline $\mathrm{T}_{10}$ : Waxing-Starlight $(25 \%)$ & 12.23 & 13.32 & 12.52 & 12.69 \\
\hline $\mathrm{T}_{11}$ : Waxing-Starlight $(50 \%)$ & 12.35 & 13.45 & 12.35 & 12.72 \\
\hline $\mathrm{T}_{12}:$ Waxing-Starlight $(75 \%)$ & 12.30 & 13.42 & 12.43 & 12.72 \\
\hline $\mathrm{T}_{13}:$ Control & 13.42 & 12.84 & 8.28 & 11.51 \\
\hline Mean & 12.40 & 13.40 & 12.30 & \\
\hline \multicolumn{5}{|l|}{ Initial value: $11.50^{\circ}$ Brix } \\
\hline \multicolumn{5}{|l|}{$\mathrm{CD}_{0.05}$} \\
\hline Treatments $(\mathrm{T})$ & & & & \\
\hline Storage Interval (I) & & & & \\
\hline $\mathrm{T} \times \mathrm{I}$ & & & & \\
\hline
\end{tabular}


Table.4 Effect of postharvest treatments on changes in reducing sugar content (\%) of apple fruits cv. Royal Delicious during ambient storage

\begin{tabular}{|c|c|c|c|c|}
\hline \multirow[t]{2}{*}{ Treatments $(\mathbf{T})$} & \multicolumn{4}{|c|}{ Storage Interval in days (I) } \\
\hline & 15 & 30 & 45 & Mean \\
\hline $\mathrm{T}_{1}: 1-\mathrm{MCP}(750 \mathrm{ppb})$ & 6.10 & 6.50 & 5.84 & 6.15 \\
\hline $\mathrm{T}_{2}: 1-\mathrm{MCP}(1000 \mathrm{ppb})$ & 6.02 & 6.42 & 5.79 & 6.08 \\
\hline $\mathrm{T}_{3}: 1-\mathrm{MCP}(1250 \mathrm{ppb})$ & 5.90 & 6.28 & 5.71 & 5.96 \\
\hline $\mathrm{T}_{4}$ : Aloe vera whole leaf extract & 6.54 & 6.94 & 5.51 & 6.33 \\
\hline $\mathrm{T}_{5}:$ Aloe vera leaf peel extract & 6.62 & 7.12 & 5.49 & 6.41 \\
\hline $\mathrm{T}_{6}$ : Aloe vera leaf gel extract & 6.50 & 6.91 & 5.54 & 6.32 \\
\hline $\begin{array}{l}\mathrm{T}_{7}: \text { Aloe vera whole leaf extract }+\mathrm{CaCl}_{2} \\
(1 \%)\end{array}$ & 6.28 & 6.72 & 5.77 & 6.26 \\
\hline $\begin{array}{l}\mathrm{T}_{8}: \text { Aloe vera leaf peel extract }+\mathrm{CaCl}_{2} \\
(1 \%)\end{array}$ & 6.36 & 6.82 & 5.68 & 6.29 \\
\hline $\mathrm{T}_{9}:$ Aloe vera leaf gel extract $+\mathrm{CaCl}_{2}(1 \%)$ & 6.26 & 6.68 & 5.84 & 6.26 \\
\hline $\mathrm{T}_{10}$ : Waxing-Starlight $(25 \%)$ & 6.48 & 6.90 & 5.60 & 6.33 \\
\hline $\mathrm{T}_{11}:$ Waxing-Starlight $(50 \%)$ & 6.39 & 6.74 & 5.74 & 6.29 \\
\hline $\mathrm{T}_{12}:$ Waxing-Starlight $(75 \%)$ & 6.35 & 6.80 & 5.83 & 6.33 \\
\hline $\mathrm{T}_{13}:$ Control & 7.24 & 6.52 & 3.48 & 5.75 \\
\hline Mean & 6.38 & 6.80 & 5.68 & \\
\hline \multicolumn{5}{|l|}{ Initial value: $5.28 \%$} \\
\hline \multicolumn{5}{|l|}{$\mathrm{CD}_{0.05}$} \\
\hline Treatments $(\mathrm{T})$ & & & & \\
\hline Storage Interval (I) & & & & \\
\hline $\mathrm{T} \times \mathrm{I}$ & & & & \\
\hline
\end{tabular}


Table.5 Effect of postharvest treatments on changes in total sugar content (\%) of apple fruits cv. Royal Delicious during ambient storage

\begin{tabular}{|c|c|c|c|c|}
\hline \multirow[t]{2}{*}{ Treatments $(\mathbf{T})$} & \multicolumn{4}{|c|}{ Storage Interval in days (I) } \\
\hline & 15 & 30 & 45 & Mean \\
\hline $\mathrm{T}_{1}: 1-\mathrm{MCP}(750 \mathrm{ppb})$ & 7.82 & 8.16 & 7.92 & 7.97 \\
\hline $\mathrm{T}_{2}: 1-\mathrm{MCP}(1000 \mathrm{ppb})$ & 7.76 & 8.08 & 7.84 & 7.89 \\
\hline $\mathrm{T}_{3}: 1-\mathrm{MCP}(1250 \mathrm{ppb})$ & 7.62 & 7.94 & 7.75 & 7.77 \\
\hline $\mathrm{T}_{4}$ : Aloe vera whole leaf extract & 8.54 & 8.81 & 7.93 & 8.43 \\
\hline $\mathrm{T}_{5}:$ Aloe vera leaf peel extract & 8.42 & 8.72 & 8.20 & 8.44 \\
\hline $\mathrm{T}_{6}:$ Aloe vera leaf gel extract & 8.45 & 8.76 & 8.02 & 8.41 \\
\hline $\begin{array}{l}\mathrm{T}_{7}: \text { Aloe vera whole leaf extract }+\mathrm{CaCl}_{2} \\
(1 \%)\end{array}$ & 8.25 & 8.48 & 8.23 & 8.32 \\
\hline $\begin{array}{l}\mathrm{T}_{8}: \text { Aloe vera leaf peel extract }+\mathrm{CaCl}_{2} \\
(1 \%)\end{array}$ & 8.32 & 8.55 & 8.19 & 8.35 \\
\hline $\mathrm{T}_{9}:$ Aloe vera leaf gel extract $+\mathrm{CaCl}_{2}(1 \%)$ & 8.20 & 8.42 & 8.29 & 8.31 \\
\hline $\mathrm{T}_{10}$ : Waxing-Starlight $(25 \%)$ & 8.42 & 8.64 & 8.20 & 8.42 \\
\hline $\mathrm{T}_{11}:$ Waxing-Starlight $(50 \%)$ & 8.37 & 8.61 & 8.35 & 8.44 \\
\hline $\mathrm{T}_{12}$ : Waxing-Starlight $(75 \%)$ & 8.35 & 8.57 & 8.39 & 8.44 \\
\hline $\mathrm{T}_{13}:$ Control & 9.28 & 8.24 & 6.85 & 8.12 \\
\hline Mean & 8.24 & 8.50 & 8.13 & \\
\hline \multicolumn{5}{|l|}{ Initial value: $7.32 \%$} \\
\hline \multicolumn{5}{|l|}{$\mathrm{CD}_{0.05}$} \\
\hline Treatments $(\mathrm{T})$ & & & & \\
\hline Storage Interval (I) & & & & \\
\hline $\mathrm{T} \times \mathrm{I}$ & & & & \\
\hline
\end{tabular}


Table.6 Effect of postharvest treatments on changes in titratable acidity content (as \% malic acid) of apple fruits cv. Royal Delicious during ambient storage

\begin{tabular}{|c|c|c|c|c|}
\hline \multirow[t]{2}{*}{ Treatments $(\mathbf{T})$} & \multicolumn{4}{|c|}{ Storage Interval in days (I) } \\
\hline & 15 & 30 & 45 & Mean \\
\hline $\mathrm{T}_{1}: 1-\mathrm{MCP}(750 \mathrm{ppb})$ & 0.27 & 0.23 & 0.19 & 0.23 \\
\hline $\mathrm{T}_{2}: 1-\mathrm{MCP}(1000 \mathrm{ppb})$ & 0.30 & 0.26 & 0.21 & 0.26 \\
\hline $\mathrm{T}_{3}: 1-\mathrm{MCP}(1250 \mathrm{ppb})$ & 0.32 & 0.28 & 0.22 & 0.27 \\
\hline $\mathrm{T}_{4}$ : Aloe vera whole leaf extract & 0.23 & 0.18 & 0.15 & 0.19 \\
\hline $\mathrm{T}_{5}:$ Aloe vera leaf peel extract & 0.20 & 0.16 & 0.12 & 0.16 \\
\hline $\mathrm{T}_{6}:$ Aloe vera leaf gel extract & 0.26 & 0.20 & 0.16 & 0.21 \\
\hline $\begin{array}{l}\mathrm{T}_{7}: \text { Aloe vera whole leaf extract }+\mathrm{CaCl}_{2} \\
(1 \%)\end{array}$ & 0.30 & 0.26 & 0.20 & 0.25 \\
\hline $\begin{array}{l}\mathrm{T}_{8}: \text { Aloe vera leaf peel extract }+\mathrm{CaCl}_{2} \\
(1 \%)\end{array}$ & 0.25 & 0.20 & 0.17 & 0.21 \\
\hline $\mathrm{T}_{9}:$ Aloe vera leaf gel extract $+\mathrm{CaCl}_{2}(1 \%)$ & 0.28 & 0.22 & 0.19 & 0.23 \\
\hline $\mathrm{T}_{10}$ : Waxing-Starlight $(25 \%)$ & 0.21 & 0.18 & 0.14 & 0.17 \\
\hline $\mathrm{T}_{11}$ : Waxing-Starlight $(50 \%)$ & 0.24 & 0.21 & 0.17 & 0.20 \\
\hline $\mathrm{T}_{12}$ : Waxing-Starlight $(75 \%)$ & 0.27 & 0.22 & 0.19 & 0.23 \\
\hline $\mathrm{T}_{13}:$ Control & 0.19 & 0.14 & 0.09 & 0.14 \\
\hline Mean & 0.26 & 0.21 & 0.17 & \\
\hline \multicolumn{5}{|l|}{ Initial value: $0.39 \%$} \\
\hline \multicolumn{5}{|l|}{$\mathrm{CD}_{0.05}$} \\
\hline Treatments $(\mathrm{T})$ & & & & \\
\hline Storage Interval (I) $\quad 0.03$ & & & & \\
\hline $\mathrm{T} \times \mathrm{I}$ & & & & \\
\hline
\end{tabular}


Table.7 Effect of postharvest treatments on changes in pectin content (as \% calcium pectate) of apple fruits cv. Royal Delicious during ambient storage

\begin{tabular}{|c|c|c|c|c|c|}
\hline \multirow{2}{*}{\multicolumn{2}{|c|}{ Treatments $(\mathbf{T})$}} & \multicolumn{4}{|c|}{ Storage Interval in days (I) } \\
\hline & & 15 & 30 & 45 & Mean \\
\hline $\mathrm{T}_{1}: 1-\mathrm{MCP}(750 \mathrm{ppb})$ & & 1.39 & 1.23 & 0.90 & 1.17 \\
\hline $\mathrm{T}_{2}: 1-\mathrm{MCP}(1000 \mathrm{ppb})$ & & 1.41 & 1.30 & 0.93 & 1.22 \\
\hline $\mathrm{T}_{3}: 1-\mathrm{MCP}(1250 \mathrm{ppb})$ & & 1.43 & 1.31 & 0.99 & 1.24 \\
\hline $\mathrm{T}_{4}:$ Aloe vera whole leaf extra & & 1.35 & 1.24 & 0.94 & 1.18 \\
\hline $\mathrm{T}_{5}$ : Aloe vera leaf peel extract & & 1.27 & 1.05 & 0.63 & 0.98 \\
\hline $\mathrm{T}_{6}:$ Aloe vera leaf gel extract & & 1.40 & 1.28 & 0.98 & 1.22 \\
\hline $\mathrm{T}_{7}$ : Aloe vera whole leaf extra & $\mathrm{Cl}_{2}(1 \%)$ & 1.45 & 1.34 & 1.02 & 1.27 \\
\hline $\mathrm{T}_{8}$ : Aloe vera leaf peel extract & $2(1 \%)$ & 1.48 & 1.38 & 1.08 & 1.31 \\
\hline $\mathrm{T}_{9}:$ Aloe vera leaf gel extract & $(1 \%)$ & 1.40 & 1.33 & 1.00 & 1.24 \\
\hline $\mathrm{T}_{10}:$ Waxing-Starlight $(25 \%)$ & & 1.37 & 1.21 & 0.67 & 1.08 \\
\hline $\mathrm{T}_{11}$ : Waxing-Starlight $(50 \%)$ & & 1.40 & 1.28 & 0.73 & 1.13 \\
\hline $\mathrm{T}_{12}:$ Waxing-Starlight $(75 \%)$ & & 1.42 & 1.30 & 0.78 & 1.17 \\
\hline $\mathrm{T}_{13}:$ Control & & 1.24 & 1.00 & 0.47 & 0.90 \\
\hline Mean & & 1.39 & 1.25 & 0.85 & \\
\hline \multicolumn{6}{|l|}{ Initial value: $1.96 \%$} \\
\hline \multicolumn{6}{|l|}{$\mathrm{CD}_{0.05}$} \\
\hline Treatments (T) & 0.01 & & & & \\
\hline Storage Interval (I) & 0.02 & & & & \\
\hline $\mathrm{T} \times \mathrm{I}$ & 0.03 & & & & \\
\hline
\end{tabular}


Table.8 Effect of postharvest treatments on changes in starch-iodine rating of apple fruits cv. Royal Delicious during ambient storage

\begin{tabular}{|c|c|c|c|c|}
\hline \multirow[t]{2}{*}{ Treatments $(\mathbf{T})$} & \multicolumn{4}{|c|}{ Storage Interval in days (I) } \\
\hline & 15 & 30 & 45 & Mean \\
\hline $\mathrm{T}_{1}: 1-\mathrm{MCP}(750 \mathrm{ppb})$ & 4.50 & 5.62 & 6.89 & 5.67 \\
\hline $\mathrm{T}_{2}: 1-\mathrm{MCP}(1000 \mathrm{ppb})$ & 4.40 & 5.52 & 6.88 & 5.60 \\
\hline $\mathrm{T}_{3}: 1-\mathrm{MCP}(1250 \mathrm{ppb})$ & 4.35 & 5.48 & 6.82 & 5.55 \\
\hline $\mathrm{T}_{4}$ : Aloe vera whole leaf extract & 5.62 & 6.70 & 7.84 & 6.72 \\
\hline $\mathrm{T}_{5}$ : Aloe vera leaf peel extract & 5.72 & 6.82 & 7.69 & 6.74 \\
\hline $\mathrm{T}_{6}:$ Aloe vera leaf gel extract & 5.54 & 6.59 & 7.75 & 6.63 \\
\hline $\begin{array}{l}\mathrm{T}_{7}: \text { Aloe vera whole leaf extract }+\mathrm{CaCl}_{2} \\
(1 \%)\end{array}$ & 5.30 & 6.38 & 7.52 & 6.40 \\
\hline $\begin{array}{l}\mathrm{T}_{8}: \text { Aloe vera leaf peel extract }+\mathrm{CaCl}_{2} \\
(1 \%)\end{array}$ & 5.38 & 6.45 & 7.59 & 6.47 \\
\hline $\mathrm{T}_{9}:$ Aloe vera leaf gel extract $+\mathrm{CaCl}_{2}(1 \%)$ & 5.20 & 6.28 & 7.42 & 6.30 \\
\hline $\mathrm{T}_{10}$ : Waxing-Starlight (25\%) & 5.52 & 6.58 & 7.72 & 6.60 \\
\hline $\mathrm{T}_{11}$ : Waxing-Starlight $(50 \%)$ & 5.42 & 6.50 & 7.64 & 6.52 \\
\hline $\mathrm{T}_{12}$ : Waxing-Starlight $(75 \%)$ & 5.39 & 6.48 & 7.62 & 6.49 \\
\hline $\mathrm{T}_{13}:$ Control & 5.75 & 6.90 & 8.05 & 6.90 \\
\hline Mean & 5.24 & 6.33 & 7.49 & \\
\hline \multicolumn{5}{|l|}{ Initial value: 4.00} \\
\hline \multicolumn{5}{|l|}{$\mathrm{CD}_{0.05}$} \\
\hline Treatments $(\mathrm{T})$ & & & & \\
\hline Storage Interval (I) & & & & \\
\hline $\mathrm{T} \times \mathrm{I}$ & & & & \\
\hline
\end{tabular}


Table.9 Effect of postharvest treatments on changes in the rate of respiration $(\mathrm{ml} \mathrm{CO} 2 / \mathrm{kg} / \mathrm{hr}$ ) of apple fruits cv. Royal Delicious during ambient storage

\begin{tabular}{|c|c|c|c|c|c|}
\hline \multirow{2}{*}{\multicolumn{2}{|c|}{ Treatments $(\mathbf{T})$}} & \multicolumn{4}{|c|}{ Storage Interval in days (I) } \\
\hline & & 15 & 30 & 45 & Mean \\
\hline \multicolumn{2}{|l|}{$\mathrm{T}_{1}: 1-\mathrm{MCP}(750 \mathrm{ppb})$} & 16.51 & 19.32 & 17.85 & 17.90 \\
\hline \multicolumn{2}{|l|}{$\mathrm{T}_{2}: 1-\mathrm{MCP}(1000 \mathrm{ppb})$} & 16.44 & 19.23 & 17.75 & 17.81 \\
\hline \multicolumn{2}{|l|}{$\mathrm{T}_{3}: 1-\mathrm{MCP}(1250 \mathrm{ppb})$} & 16.41 & 19.21 & 17.71 & 17.77 \\
\hline \multicolumn{2}{|l|}{$\mathrm{T}_{4}$ : Aloe vera whole leaf extract } & 19.29 & 25.65 & 22.59 & 22.51 \\
\hline \multicolumn{2}{|l|}{$\mathrm{T}_{5}$ : Aloe vera leaf peel extract } & 19.33 & 25.72 & 22.69 & 22.58 \\
\hline \multicolumn{2}{|l|}{$\mathrm{T}_{6}$ : Aloe vera leaf gel extract } & 19.26 & 25.64 & 22.58 & 22.50 \\
\hline \multicolumn{2}{|c|}{$\mathrm{T}_{7}$ : Aloe vera whole leaf extract $+\mathrm{CaCl}_{2}(1 \%)$} & 19.21 & 25.56 & 22.49 & 22.42 \\
\hline \multicolumn{2}{|c|}{$\mathrm{T}_{8}:$ Aloe vera leaf peel extract $+\mathrm{CaCl}_{2}(1 \%)$} & 19.26 & 25.59 & 22.51 & 22.45 \\
\hline \multicolumn{2}{|c|}{$\mathrm{T}_{9}$ : Aloe vera leaf gel extract $+\mathrm{CaCl}_{2}(1 \%)$} & 19.19 & 25.52 & 22.42 & 22.38 \\
\hline \multicolumn{2}{|l|}{$\mathrm{T}_{10}$ : Waxing-Starlight (25\%) } & 17.12 & 21.46 & 19.47 & 19.35 \\
\hline \multicolumn{2}{|l|}{$\mathrm{T}_{11}$ : Waxing-Starlight (50\%) } & 16.98 & 21.38 & 19.35 & 19.24 \\
\hline \multicolumn{2}{|l|}{$\mathrm{T}_{12}$ : Waxing-Starlight (75\%) } & 16.88 & 21.29 & 19.25 & 19.14 \\
\hline \multicolumn{2}{|l|}{$\mathrm{T}_{13}$ : Control } & 20.58 & 18.35 & 16.82 & 18.59 \\
\hline \multicolumn{2}{|l|}{ Mean } & 18.19 & 22.61 & 20.27 & \\
\hline \multicolumn{6}{|l|}{ Initial value: $15.35 \mathrm{ml} \mathrm{CO}_{2} / \mathrm{kg} / \mathrm{hr}$} \\
\hline \multicolumn{6}{|l|}{$\mathrm{CD}_{0.05}$} \\
\hline Treatments $(\mathrm{T})$ & \multicolumn{5}{|l|}{0.03} \\
\hline Storage Interval (I) & \multicolumn{5}{|l|}{0.01} \\
\hline T x I & \multicolumn{5}{|l|}{0.05} \\
\hline
\end{tabular}


Table.10 Effect of postharvest treatments on overall acceptability rating (on 9-point hedonic scale) of apple fruits cv. Royal Delicious during ambient storage

\begin{tabular}{|c|c|c|c|c|}
\hline \multirow[t]{2}{*}{ Treatments $(\mathbf{T})$} & \multicolumn{4}{|c|}{ Storage Interval in days (I) } \\
\hline & 15 & 30 & 45 & Mean \\
\hline $\mathrm{T}_{1}: 1-\mathrm{MCP}(750 \mathrm{ppb})$ & 7.76 & 6.74 & 5.78 & 6.76 \\
\hline $\mathrm{T}_{2}: 1-\mathrm{MCP}(1000 \mathrm{ppb})$ & 7.80 & 6.78 & 5.82 & 6.80 \\
\hline $\mathrm{T}_{3}: 1-\mathrm{MCP}(1250 \mathrm{ppb})$ & 7.84 & 6.82 & 5.85 & 6.84 \\
\hline $\mathrm{T}_{4}$ : Aloe vera whole leaf extract & 7.22 & 6.20 & 5.23 & 6.22 \\
\hline $\mathrm{T}_{5}$ : Aloe vera leaf peel extract & 7.20 & 6.18 & 5.15 & 6.18 \\
\hline $\mathrm{T}_{6}:$ Aloe vera leaf gel extract & 7.23 & 6.22 & 5.21 & 6.22 \\
\hline $\begin{array}{l}\mathrm{T}_{7}: \text { Aloe vera whole leaf extract }+\mathrm{CaCl}_{2} \\
(1 \%)\end{array}$ & 7.30 & 6.28 & 5.30 & 6.29 \\
\hline $\begin{array}{l}\mathrm{T}_{8}: \text { Aloe vera leaf peel extract }+\mathrm{CaCl}_{2} \\
(1 \%)\end{array}$ & 7.26 & 6.26 & 5.25 & 6.26 \\
\hline $\mathrm{T}_{9}$ : Aloe vera leaf gel extract $+\mathrm{CaCl}_{2}(1 \%)$ & 7.32 & 6.32 & 5.30 & 6.30 \\
\hline $\mathrm{T}_{10}$ : Waxing-Starlight $(25 \%)$ & 7.44 & 6.42 & 5.41 & 6.43 \\
\hline $\mathrm{T}_{11}$ : Waxing-Starlight $(50 \%)$ & 7.48 & 6.46 & 5.46 & 6.47 \\
\hline $\mathrm{T}_{12}$ : Waxing-Starlight $(75 \%)$ & 7.54 & 6.51 & 5.51 & 6.52 \\
\hline $\mathrm{T}_{13}:$ Control & 7.12 & 6.05 & 5.12 & 6.10 \\
\hline Mean & 7.43 & 6.40 & 5.42 & \\
\hline \multicolumn{5}{|l|}{ Initial value: 8.50} \\
\hline \multicolumn{5}{|l|}{$\mathrm{CD}_{0.05}$} \\
\hline Treatments (T) & & & & \\
\hline Storage Interval (I) & & & & \\
\hline $\mathrm{T} \times \mathrm{I}$ & & & & \\
\hline
\end{tabular}


Table.11 Effect of some post-harvest treatments on spoilage* (\%) of apple fruits cv. Royal Delicious apples during ambient storage

\begin{tabular}{|c|c|c|c|c|}
\hline \multirow[t]{2}{*}{ Treatments $(\mathbf{T})$} & \multicolumn{4}{|c|}{ Storage Interval in days (I) } \\
\hline & 15 & 30 & 45 & Mean \\
\hline $\mathrm{T}_{1}: 1-\mathrm{MCP}(750 \mathrm{ppb})$ & $\begin{array}{c}0.00 \\
(0.71)\end{array}$ & $\begin{array}{c}2.24 \\
(1.65)\end{array}$ & $\begin{array}{c}4.32 \\
(2.20)\end{array}$ & $\begin{array}{c}2.18 \\
(1.52)\end{array}$ \\
\hline $\mathrm{T}_{2}: 1-\mathrm{MCP}(1000 \mathrm{ppb})$ & $\begin{array}{c}0.00 \\
(0.71)\end{array}$ & $\begin{array}{c}2.11 \\
(1.62)\end{array}$ & $\begin{array}{c}3.91 \\
(2.10)\end{array}$ & $\begin{array}{c}2.01 \\
(1.47)\end{array}$ \\
\hline $\mathrm{T}_{3}: 1-\mathrm{MCP}(1250 \mathrm{ppb})$ & $\begin{array}{c}0.00 \\
(0.71)\end{array}$ & $\begin{array}{c}1.98 \\
(1.58)\end{array}$ & $\begin{array}{c}3.72 \\
(2.06)\end{array}$ & $\begin{array}{c}1.90 \\
(1.45)\end{array}$ \\
\hline $\mathrm{T}_{4}$ : Aloe vera whole leaf extract & $\begin{array}{c}0.00 \\
(0.71)\end{array}$ & $\begin{array}{c}2.26 \\
(1.66)\end{array}$ & $\begin{array}{c}3.80 \\
(2.07)\end{array}$ & $\begin{array}{c}2.02 \\
(1.48)\end{array}$ \\
\hline $\mathrm{T}_{5}$ : Aloe vera leaf peel extract & $\begin{array}{c}0.00 \\
(0.71)\end{array}$ & $\begin{array}{c}2.42 \\
(1.71)\end{array}$ & $\begin{array}{c}4.08 \\
(2.14)\end{array}$ & $\begin{array}{c}2.16 \\
(1.52)\end{array}$ \\
\hline $\mathrm{T}_{6}$ : Aloe vera leaf gel extract & $\begin{array}{c}0.00 \\
(0.71)\end{array}$ & $\begin{array}{c}2.38 \\
(1.70\end{array}$ & $\begin{array}{c}3.96 \\
(2.11)\end{array}$ & $\begin{array}{c}2.11 \\
(1.51)\end{array}$ \\
\hline $\begin{array}{l}\mathrm{T}_{7} \text { : Aloe vera whole leaf extract }+\mathrm{CaCl}_{2} \\
(1 \%)\end{array}$ & $\begin{array}{c}0.00 \\
(0.71)\end{array}$ & $\begin{array}{c}1.10 \\
(1.26)\end{array}$ & $\begin{array}{c}2.24 \\
(1.66)\end{array}$ & $\begin{array}{c}1.11 \\
(1.21)\end{array}$ \\
\hline $\mathrm{T}_{8}$ : Aloe vera leaf peel extract $+\mathrm{CaCl}_{2}(1 \%)$ & $\begin{array}{c}0.00 \\
(0.71)\end{array}$ & $\begin{array}{c}1.98 \\
(1.58)\end{array}$ & $\begin{array}{c}3.25 \\
(1.94)\end{array}$ & $\begin{array}{c}1.74 \\
(1.41)\end{array}$ \\
\hline $\mathrm{T}_{9}:$ Aloe vera leaf gel extract $+\mathrm{CaCl}_{2}(1 \%)$ & $\begin{array}{c}0.00 \\
(0.71)\end{array}$ & $\begin{array}{c}1.22 \\
(1.31)\end{array}$ & $\begin{array}{c}2.92 \\
(1.85)\end{array}$ & $\begin{array}{c}1.38 \\
(1.29)\end{array}$ \\
\hline $\mathrm{T}_{10}$ : Waxing-Starlight (25\%) & $\begin{array}{c}0.00 \\
(0.71)\end{array}$ & $\begin{array}{c}2.32 \\
(1.68)\end{array}$ & $\begin{array}{c}4.41 \\
(2.22)\end{array}$ & $\begin{array}{c}2.24 \\
(1.53)\end{array}$ \\
\hline $\mathrm{T}_{11}$ : Waxing-Starlight (50\%) & $\begin{array}{c}0.00 \\
(0.71)\end{array}$ & $\begin{array}{c}2.19 \\
(1.64)\end{array}$ & $\begin{array}{c}3.99 \\
(2.12)\end{array}$ & $\begin{array}{c}2.06 \\
(1.49)\end{array}$ \\
\hline $\mathrm{T}_{12}$ : Waxing-Starlight $(75 \%)$ & $\begin{array}{c}0.00 \\
(0.71)\end{array}$ & $\begin{array}{c}2.02 \\
(1.59)\end{array}$ & $\begin{array}{c}3.78 \\
(2.07)\end{array}$ & $\begin{array}{c}1.93 \\
(1.46)\end{array}$ \\
\hline $\mathrm{T}_{13}$ : Control & $\begin{array}{c}0.00 \\
(0.71)\end{array}$ & $\begin{array}{c}4.92 \\
(2.33)\end{array}$ & $\begin{array}{c}8.74 \\
(3.04)\end{array}$ & $\begin{array}{c}4.55 \\
(2.03)\end{array}$ \\
\hline Mean & $\begin{array}{c}0.00 \\
(0.71)\end{array}$ & $\begin{array}{c}2.24 \\
(1.64)\end{array}$ & $\begin{array}{c}4.09 \\
(2.12)\end{array}$ & \\
\hline \multicolumn{5}{|l|}{$\mathrm{CD}_{0.05}$} \\
\hline \multicolumn{5}{|l|}{ Treatments (T) $\quad 0.01$} \\
\hline Storage Interval (I) $\quad 0.02$ & \multicolumn{4}{|c|}{0.02} \\
\hline \multicolumn{5}{|l|}{$\begin{array}{ll}\mathrm{T} \times \mathrm{I} & 0.04\end{array}$} \\
\hline
\end{tabular}

*Figures in parentheses are square root transformed values

On the other hand the control fruits exhibited a faster increase in the respiration rate upto 15 days during storage and the subsequent decrease in respiration of these fruits was also faster. The control fruits therefore had the lowest respiration rate on the $45^{\text {th }}$ day of storage. Other treatments exhibited an increase in the respiration rate upto 30 days before declining gradually during subsequent storage. The interaction between treatments and storage intervals was found to be significant. Lower rate of respiration in fruits 
treated with 1-MCP in comparison to other treatments could be due to its ability to inactivate ethylene, thus reducing the respiration rate of apple fruits. 1-MCP is an ethylene action inhibitor acting at very low concentrations, which has been reported to delay ripening and enhance storage life in intact and fresh cut fruits (Antunes et al., 2008).

\section{Effect on sensory evaluation}

\section{Overall acceptability rating}

Data in Table 10 represents the effect of various postharvest treatments on overall acceptability rating of apple fruits during ambient storage. A perusal of the data shows that the score for overall acceptability decreased during the entire 45 day storage period under all the treatments. The decrease was faster in control fruits which were ultimately rated to be the least acceptable. However, the treatment $\mathrm{T}_{3}(1250 \mathrm{ppb} 1-\mathrm{MCP}$ fumigation) resulted in maximum mean acceptability rating of fruit (6.84) and it was followed by $T_{2}, T_{1}$ and $T_{12}$, respectively. Interactions between treatments and storage intervals were found to be significant. Sensory quality is a criteria for determining the acceptability of any food or food product by the consumers. Overall acceptability of food in addition to quality and nutritional attributes also depends on the sensory quality. Improvement in palatability rating of guava fruit with 1-MCP treatment has also been reported by Bassetto et al., (2005) and Mahajan and Singh (2008).

\section{Effect on fruit spoilage}

Data presented in the Table 11 shows the extent of spoilage in apple fruits cv. Royal Delicious in response to different postharvest treatments. The minimum mean fruit spoilage (1.11\%) was recorded with $\mathrm{T}_{7}$ (Aloe vera whole leaf extract +1.0 per cent $\mathrm{CaCl}_{2}$ ) which was significantly lower in comparison to all other treatments and was followed by Aloe vera leaf gel extract +1.0 per cent $\mathrm{CaCl}_{2}\left(\mathrm{~T}_{9}\right)$ and $1250 \mathrm{ppb} 1-\mathrm{MCP}\left(\mathrm{T}_{3}\right)$, respectively, although all other treatments also caused significant reductions in spoilage over the control fruits where maximum spoilage $(4.55 \%)$ was recorded. During storage spoilage was not detected in any of the treatments upto 15 days which increased significantly to 2.24 and 4.09 per cent by the $30^{\text {th }}$ and $45^{\text {th }}$ day, respectively. Reductions in spoilage with botanical extracts have also been reported by Singh et al., (2000) and Bhardwaj and Sen (2003) on mango and Nagpur mandarins, respectively. Aloe vera based coatings have been reported to prevent loss of moisture and firmness, control respiratory rate, maturation and reduce microorganism proliferation in fruits such as sweet cherry (Martinez-Romero et al., 2006), table grapes (Valverdo et al., 2005) and nectarines (Ahmed et al., 2009).

\section{Acknowledgement}

This study was funded by Dr. Yashwant Singh Parmar University of Horticulture and Forestry, Nauni, Solan.

\section{References}

Ahmed, M. J., Singh, Z. and Khan, A. S. 2009. Postharvest Aloe vera gel-coating modulates fruit ripening and quality of 'Arctic Snow' nectarine kept in ambient and cold storage. International Journal of Food Science and Technology, 44: 1024-1033.

Antunes, M., Miguel, M., Metelo, S., Dandlen, S. and Cavaco, A. 2008. Effect of 1-methylcyclopropene application prior to storage on fresh cut kiwifruit quality. Acta Horticulturae, 796: 173-178. 
Asif, A. 2002. Apple the sweet gold of Pakistan. Export Promotion Bureau of Pakistan.

Awasthi, R. P. and Chauhan, P. S. 2002. Apple. In: Handbook of Horticulture, KL Chadha (ed.). Indian Council of Agricultural Research, New Delhi.1119 p.

Ball, J. 1997. Evaluation of Two Lipid-Based Edible Coatings for their Ability to Preserve Post Harvest Quality Characteristics of Green Bell Peppers. M.S. thesis. Virginia Polytechnic Institute and Statue University, Blacksburg, VA.

Bassetto, B., Jacomino, A. P., Pinheiro, A. L. and Kluge, R. A. 2005. Delay of ripening of "Redro Sato" guava with 1methylcyclopropene. Postharvest Biology and Technology, 35: 303-308.

Betts, H. A. and Bramlage, W. J. 1977. Uptake of calcium by apple from postharvest dip in calcium chloride solutions. Journal of American Society for Horticultural Sciences, 102: 785788.

Bhardwaj, R. L. and Sen, N. Z. 2003. Zero energy cool chamber storage of mandarin (Citrus reticulate cv. Nagpur Santra). Journal of American Society for Horticultural Sciences, 40 (6): 669-672.

Doesburg, J. J. 1957. Relationship between the solubilization of pectin and the fate of organic acids during maturation of apples. Journal of Science of Food and Agriculture, 8: 206-216.

FAO. $2008 . \quad$ http:// faostat.fao.org/site/567/default.aspx

Faust, M. and Klein, J. D. 1974. Levels and sites of metabolically active calcium in apple fruit. Journal of the American Society for Horticultural Sciences, 99: 93-94.

Gakhukar, R. T. 1996. Commercial and industrial aspects of neem based pesticide. Pestology, 22 (10):15-32.
Lester, G. E. and Grusak, M. A. 1999. Post harvest application of calcium and magnesium to Honeydew and Netted Muskmelon: effects on tissue ion concentrations, quality and senescence. Journal of the American Society for Horticultural Science, 124: 545-555.

Mahajan, B. V. C. and Singh, G. 2008. Effect of 1-MCP on storage life and quality of winter guava. Journal of Food Science and Technology, 45: 537-539.

Martinez-Romero, D., Serrano, M., Valero, D. and Castillo, S. 2003. Application de Aloe vera como recubrimicento Stobre frutas Yhor taliza. Spain patent200302937.

Martinez-Romero, D. L., Alburquerque, N., Valverde, J. M., Guillen, F. and Castillo, S. 2006. Post harvest cherry quality and safety maintenance by Aloe vera treatment: A new edible coating. Postharvest Biology and Technology, 39: 93-100.

Poapst, P. A., Ward, G. M. and Phillips, W. R. 1959. Maturation of Mclntosh apples in relation to starch loss and abscission. Canadian Journal of Plant Science, 29: $251-263$.

Ranganna, S. 1986. Manual of Analysis of Fruits and Vegetable Products. Tata McGraw Hill Publishing Company Ltd. New Delhi.

Rodriguez de Jasso, D., Hernandez-Castillo, D., Rodriguez-Garcia, R. and AnguloSanchez, J. L. 2005. Antifungal activity in vitro of Aloe vera pulp and liquid fraction against pathogenic fungi. Indian Crop Production, 21: 81-87

Saks, Y. and Barkai-Golan, R. 1995. Aloe vera gel activity against plant pathogenic fungi. Postharvest Biology and Technology, 6: 159-165.

Sandhu, K. S., Bhatia, B.. S and Shukla, F. C. 1990. Effect of lye treatment on the quality of Kinnow juice. Indian Journal of Horticulture, 47: 55-59. 
Sharma, R. N., Tare, V. and Vartak, P. H. 1997. Bio-activity of some natural oils from Himalayan region different insect. Indian Journal of Science and Research, 1 (1): 16-18.

Singh, J. N., Acharya, P. and Singh, B. B. 2000. Effect of GA3 and plant extracts on storage behaviour of mango (Mangifera indica) cv. Langra. Haryana Journal of Horticultural Sciences, 29: 3-4.

Sisler, E. C. and Serek, M. 1997. Inhibitor of ethylene responses in plants at the receptor level: recent developments. Physiologia Plantae, 100: 577-582.

Streif, J. 2007. Regulation of postharvest fruit ripening by innovative storage technology. Acta Horticulturae, 804: 462-471.

Suni, M., Nyman, M., Eriksson N. A., Bjork, L. and Bjork, I. 2000. Carbohydrate composition and content of organic acids in fresh and stored apples. Journal of Science of Food and Agriculture, 80 (10): 1538-1544.

Ulrich, R.1974. Organic acids. In: Biochemistry of Fruits and their products (Ed. A. C. Hulme). 89-118 pp. Valverde, J. M., Valero, A., MartinezRomero, D., Guillen, F. and Castillo, S. 2005. Novel edible coating based on Aloe vera gel to maintain table grape quality and safety. Journal of Agriculture and Food Chemistry, 53: 7807-7813.

Vargas, M., Pastov, C., Chirau, A., Clements, M. C, Julian, D. and GunzalezMartinez, C. 2008. Recent advances in edible coatings for fresh and minimally processed fruits. Food Science Nutrition, 48: 496-511.

Wilkinson, B. G. 1965. Some effects of storage under different conditions of humidity on the physical properties of apple. Journal of Horticultural Sciences, 40: 58-65.

Wills, R. B. H., Bembridge, P. A. and Scott, K. J. 1980. Use of flesh firmness and other objective tests to determine consumer acceptability of delicious apples. Australian Journal of Agriculture and Animal Husbandry, 20: 252-256.

\section{How to cite this article:}

Sharma Anshu. 2019. Effect of Some Postharvest Treatments on Storage Quality of Apple cv. Royal Delicious under Ambient Storage. Int.J.Curr.Microbiol.App.Sci. 8(04): 533-553. doi: https://doi.org/10.20546/ijcmas.2019.804.058 